\title{
Family Structural Norms Leading to Gender Disparity in Pakistan
}

\author{
Dr. Safdar Rehman Ghazi \\ Assistant Professor, University of Science and Technology, Bannu, Pakistan \\ E-mail: drsrghazi@yahoo.com \\ Dr. Saqib Shahzad \\ Assistant Professor, University of Science and Technology, Bannu, Pakistan \\ Gulap Shahzada \\ Lecturer, University of Science and Technology Bannu, Pakistan \\ Uzma Syeda Gillani \\ Lecturer, University of Science and Technology Bannu, Pakistan \\ Muhammad Rashid Khan \\ M.Phil Scholar, University of Science and Technology, Bannu, Pakistan
}

\begin{abstract}
The major purpose of this study was to explore the, "Family Structural Norms Leading to Gender Disparity in Pakistan". It was concluded that Females are not consulted regarding their higher education, proper transport facilities are not managed by universities for female students, females have less access to higher education, There are inadequate and a very small number of women's universities, family structural norms found not supportive for female education, females located in either urban or rural areas are facing the same problem of gender disparity regarding their education, and they have the same views that family structural norms are not supporting for their education. On the basis of these conclusions it is recommended that females should have the freedom to make their own decisions, especially regarding their education, proper transportation facilities should be arranged or managed them, it is necessary to enhance females' enrolment in each and every tier and streamline of education to bring equity in gender, more women s' universities should be established, Legislation should be done at central level as well as at provincial level to enhance the females' enrolment in all tiers of education and all streamlines, and 50\% seats should be reserved for female students in every discipline in the universities.
\end{abstract}

Keywords: Family norms, Structural norms, Gender disparity, Female education

\section{INTRODUCTION}

Crapo (2000) sheered that society be actively self leading, self-fascinated group of human being, which live in an area, share way of life and have the majority of its links inside this group. It refers to a crowd of citizens; continue to exist within the same area which donates to universal institutions. It is an organization of general public who contribute to a common region, manage them, and co-operate to protect the survival of the group. It is the cluster of citizens who envisage themselves as distinct from other groups and who are connected together through communicational binds, common customs and traditions, and institutions such as politics, law and economics.

Berry (2000) and Matsumoto (2001) describe that Culture is the system of human being, which is approved and resting on it since after their creation. It is the manifold whole based on information, faith, painting, ethics, rule, way of life and in the slightest further ability and lifestyle acquired through gentleman like a portion of the general public. It refers to the collective inheritance of citizens -folks, cultured pattern intended for thoughts, approach, and performance that are transmitted as a single creation after their birth, counting the personification of these patterns in objects. From their existence experience, citizens expand to put a set of laws and actions for 
gathering their wants. The rest of system and actions, jointly by a sustaining rest of thoughts and value, be a civilization. Culture refers to the conduct pattern, belief, and every further yield of an exacting set of citizens that be accepted from one age group to another age group. These products result since the interactions among groups of citizens and their environments more than several existences. A civilizing set preserve to live at the same time like outsized the United States otherwise like minute as an isolated Amazon tribe. What its extent may be, the group way of life influence the performance of its member.

Chaefer (2003) states, that standards Norms are that standards that define the obligatory and expected behaviors of people in various situations. This reflects belief of society about correct and incorrect behaviors. Once these behaviors become second nature, members of a society, do not able to analyze every situation consciously and decide what there appropriate actions ought to be. Norms also can inhibit the type of thinking that might result in challenges to the dominant members of society. Clean hand prior, to feast." "Thou shalt not kill." "Respect your elders." every society have habits of encouraging which enforce what they sight suitable behaviors, though discourage as well as laborious what they believe near to exist unacceptable behaviors. Norms are established standards of behavior maintain through civilization. Proper standard usually include in black and white, which also identify firm punishment for folklore violators. In U. S, frequently honor norm keen on law, should be fixed inside important right along with inappropriate actions. Unofficial norm are usually unwritten and are not accurately recorded. Usually suitable uniform are a general illustration of unofficial norm. Standard is too classified through their virtual value toward civilization. While classify into this method, these be identified like civilization as well as Folklore. Ethnicity is norm, extremely essential for the wellbeing of the general public, frequently as these represent nearly every appreciated value of citizens. Every civilization, stress conformity toward the way of life, infringement is able to direct toward strict penalty. Folklore is norm principal daily performance. Folklore participate vital part within determining every day performance, each member of society.

Wikipedia (2008) explains socio-cultural norms of Pakistan. The language of Pakistani society is Urdu, representing diverse culture among ethnic groups from Punjab as well as Sindh which are situated to east of the tribal cultures of Baloch and Pukhtun and to the north, the ancient Dardic people residu in. Pakistani culture has been affected by the sorrounding cultures of the countries like Afghanistan, Iran, Iindia, Central Asia, Middle East and etc, in ancient Periods, like Indus Valley Civilization, South Asian Foundation as well as Afghan Culture. The society of Pakistan (Urdu): comprises diverse cultures and ethnic groups from the Punjabis and Sindhis in the east to the tribal cultures of the Baloch and Pashtun, as well as the ancient Dardic people inhabiting to the north. The culture have been greatly influenced by and have themselves influenced many of the surrounding countries cultures, such as those of Afghanistan, Iran, India, Central Asia and the Middle East along with other places. Pakistan in ancient times was a major cultural hub, the home of ancient civilizations, including the Indus Valley Civilization, the foundation of South Asian and Afghan culture. From the rulers of this territories, several cultural practices along with monuments have been inherited which have added civilization to this areas. Persian Empire has greatly influenced too many cultures Just like Afghan Empire, and afterword short lived but influential Mughal Empire.

Maqsood (2004) states Islamic culture as, The Quran address on the way to every Muslims, as well as on behalf of the majority element it does not discriminate between masculine as well as feminine. Masculine and feminine, this say, "Were created of a single soul," as well as are ethical age group in the view of Spirit. Female encompass the accurate to dissociate, to be left material goods, to carry out trade as well as admittance in the direction of comprise awareness.

About polygamy, the Quran endorses that one male can marry with maximum of four females at a time. Our Holly Prophet (PBUH), when advented, the occasion was very verse. Frequent fighting shaped great figures of widows, who missing their mates' while other members of the family were in refusal condition on behalf of them as well as their offspring. Once follower of Islam depart this life, firm law direct the parts of possessions along with wealth might run off to his relatives; female kids as a rule become heir to fewer as compare to male kids, however this is for the reason, the male within a family unit are believed to afford the whole family. At last, here is the matter of charitable eyewitness. While the Quran says clear rejection, others Islamic sources propose to facilitate a female's proof within are worth merely partially to a male. This decision though, be supposed to functional just circumstance anywhere a female be unqualified, must led an extremely limited existence. Female likewise capable near a male spirit hold the similar power while an eyewitness

Afridi (2003) describes about the Socio-Culture Norms of North West Frontier Province as that Admiration on behalf of female be too clear from the truth so as to she is not interfere by within casing of family conflict, blood feud, town affrays brawl. Puthan females act not examine the usual veil however they used to put on Burqa whilst visiting toward city or else far-flung places outside the vicinity. During out-of-doors function, they though, 
envelop visage in addition to body by sheet (Dopatta). Why the clannish females do not put on Burqa or else watch Purdah (veil) as is vague in municipal area, is not easy to explain? Puthan females put on effortless clothes. These include of trousers, Shirt and a scarf. Aged females favor unfastened along with loose trousers, extended shirts by wider sleeves as well as dyed dress. Puthan believe to act into accordance the values of Islamic rule i.e. an eye for an eye, a tooth for a tooth, as well as blood for blood. He wipes away rudeness with rudeness despite of charge or else end results, moreover vindicates his respect by wipe away dishonor through appropriate action. Although insist on for avenge do not mean accordingly when to be savage, blood dry or devoid of humanitarian behavior. He is too kind, loving, pleasant, and generous as well as forgives one, who kills his family member with fault. However he decides not to permit one planned put to death, depart from him, not living un-avenged. Self-important of his dive, become odious just as an abuse is hurl and a few wound be made to him intentionally. He goes in look for his foe; scan the adjacent region as well as hill, dishonesty into remain used for months or years, undergo every hardship except do not think satisfied cultivate his pains of wreak revenge resting on his rival are crown by victory. Persons, not succeed to do the obligation of self-respect by wipe away abuse, go down their status in the eye of their compatriot, provide themselves likely to reproach as well as earn undue person's name. According to set laws of respect an un-avenged wound is the genuine disgrace along with admiration of the individual can be redeem merely with alike deed. It might, though, be famous so as to "there is little if any random crime or violence" in the ethnic area while the stake be as well tall with the revenge also sure to pursue.

Santrock (2004) refers the Gender to the socio-cultural along with emotional scope of organism feminine or masculine. It is distinguish from sex, which involve the biological scope of creature feminine or masculine. Sex role be the societal prospect that recommend how masculine as well as feminine ought to believe, proceed, and feel to do.

Kottak (2004), states that Sexual Differences Humans are biological creatures as well as cultural beings. Female and males differ biologically in various ways. Generally, females contain a pair of X (XX) chromosomes, as well as males contain one $\mathrm{X}$ chromosome and one $\mathrm{Y}$ chromosome (XY). Since only males carry one $\mathrm{Y}$ chromosome, a child by gender is determined whether it received an $\mathrm{X}$ or a $\mathrm{Y}$ chromosome from its father.

Hughes, et al (2002) describe the Gender Stratification as that Gender refers to presents if individual is hereditarily masculine otherwise feminine, which determine the genetic responsibility that individual will take part in imitation. Gender, additionally, is a type of societal demarcation; it presents the socio-cultural difference involving masculine as well as feminine. Although gender is a set in natural world, sex is a publicly construct structure of creature have shaped to create intelligence as well as deal with the gender distinction. Gender function is rest upon educational prospect that describe the habits in which the member of every gender ought to perform. Gender roles influence a wide range of human behaviors, including how group tell, uniform, march, connect in courtship, irritated, engage games, contract with suffering, and decide a profession. The gender roles defined by a society have profound penalty on behalf of the life of its males as well as females. They constitute master statuses that bear prime burden within people's contact also relationship by others. In doing so they place men and women in the social structure, establishing where and what they are in social terms. Thus, gender role establish the framework within which men and women get their identities, formulate their goals, and carry out their training. Gender roles are a major source of social inequality.

Isani and Virk (2005) state the Gender Disparity as that the disparities are more obvious in gender, region and other disadvantaged groups. To be a woman, according to Dr Mahbub ul Haq (1997), in the South Asian region is to be a non-person. Here poverty has a women's face. Women are deprived of the right of entry to educational, financial, political and societal opportunities to develop. Then there are gross regional disparities and also between rural and urban areas of various provinces.

Yasmin (2005) describes about the Women Rights in Pakistan that Female's rights globally are an essential pointer of accepting worldwide welfare. 'Female's rights in Pakistan' is immense queries frequently rise in the west. It is assumed that females contain no civil rights in the man subjugated society of Pakistan. Pakistan is identified as the Islamic state of Pakistan. Islam is the religion of the state. The massive gatherings of the nation are Muslims. The Islamic set of laws of living as well as belief is the supreme to be gained by state.

Feminine and masculine comprise alike civil rights in Islam. In the pious and religious aspect of livelihood the person have the same norms of reality, truthfulness, modesty, fairness as well as honesty, appeal and contributions are enjoined for the men as well as women alike, which are judged, punished and rewarded by the same values. Moreover, up till now payable attention are given to the way of life and mores in Muslim country. While Islamic justice towards feminine is absent. 
The charter of the Islamic state of Pakistan 1973 guarantees females alike rights with males. The basic human rights provide lawful security to females. Carry out and legal rights are not equal. Numerous of these legal guarantee transparently unnoticed nearly in all walk of daily live. Prejudice is clear the world over. Pakistani civilization generally adopts aggressive manner towards the females. Their progress in civilization is delayed due to various factors.

Qureshi and Rarieya (2007) state the Female's Education in Pakistan as that the constitution of Pakistan (1973) promises equal rights to all citizens repudiates discrimination on the basis of sex alone, and affirms steps to ensure full participation of women in all spheres of life. The constitutional assertion and emphasis on equal rights and opportunities for women was meant to address the traditionally low social status and minimal participation of women in most social sectors. In the years 1949-50 two years after Pakistan's independence in 1947, overall gross participation rates at primary and secondary levels were low at 16 per cent and 9 per cent respectively.

Haq (2000) describes about the Constraints to Girl's Education that complex and interrelated factors are responsible for the low educational attainment of girls in the region. In some cases, these are country specific but many factors are common to all south Asian countries. Low female participation in the education system is primarily the outcome of two factors: low parental demand for girls schooling; and the public and private sectors supply of educational services that do not respond to the communities' needs. Traditionally, supply-related factors have received more attention. It was thought that with enough schools, teachers and textbooks, the education system would produce the desired outcome for girls and boys alike. However it is increasingly becoming apparent that these factors are necessary but not entirely sufficient for ensuring required enrolment and achievements rates. It is thus important to address the constraints related to demand as well supply. One of the most significant factors that inhibit woman's access to education in South Asia is the perception that the investment in educating a girl will not benefit her parents once the girl gets married. Further, south Asia cultures place a high value on the chastity of girls, and therefore, parents are often reluctant to allow their daughters to be taught by male teachers, to enroll in school without separate facilities for girls, or to attend boarding schools in distant towns.

The empowerment of women is recognized as the central issue for determining the status of women. Among the socially disadvantages groups, women are the victims of gender discrimination and deprivation. Despite progress in implementing women's empowered and gender equality programs in national plans, there were still a long way to go to ensure full gender equality (Chakrabarti, 2001).

Patriarchal values, embedded in Pakistani Society, and in its local traditions and cultures, predetermine the social value of gender. Low level of resource investment in women by the family and the state causes gender disparity. It provides them with greater opportunity and choice to improve their lives and that of their families. Education is the key to overcoming oppressive custom and traditions that have negated the needs of girls and women (Khan, 2007).

Human resource progress is only achievable if men and women of the country are highly knowledgeable as well as skillful. Therefore, this study seeks to investigate, "Family Structural Norms Leading to Gender Disparity in Pakistan.

\section{STATEMENT OF THE PROBLEM}

The major purpose of the study is to investigate the Family Structural Norms, Leading to Gender Disparity in Pakistan.

\section{OBJECTIVES OF THE STUDY}

1. To obtain the views of the female students regarding their family structural norms leading to gender disparity,

2. To compare the views of the students from urban and rural areas on family structural norms leading to gender disparity, and

3. To give recommendations to minimize, the gender gap in the Pakistani society and particularly at university education.

\section{DELIMITATIONS OF THE STUDY}

Due to time and resources constraints, this study is delimited to the views of female students studying in public sector universities in Khyber Pakhtun Khwa Province of Pakistan.

\section{SIGNIFICANCE}


1. To increase the Gross Enrolment Rate (GER) as well as Net Enrolment Rate at all levels and streamlines of education.

2. To minimize, the gender gap in all fields of life at local, provincial and national level.

3. To empower the women to increase personal rate of return as well as social rate of return.

4. To attract the attentions of scholars, researchers and educators towards this crucial problem

\section{POPULATION AND SAMPLE}

All the enrolled female students as a whole are taken as a sample in public sector Khyber Pakhtoon Khwa province. Two stages random sampling technique is used. Out of seven public sector universities, four universities were taken. From each sampled university, 100 students were taken, of which 50 were urban and 50 were rural by location. Thus 400 students were sampled, in which 200 were urban and 200 were rural.

\section{INSTRUMENTATION}

A self-developed questionnaire based on five point Likert scale was used in this study. The questionnaire was administered by the researcher personally and $100 \%$ target was achieved in this way. The collected data entered in SPSS 16 and the results were generated using Mean, Standard Deviation and Independent Samples t-test.

\section{DATA ANALYSIS}

The data collected through research instrument is tabulated, analyzed and interpreted in the light of objectives of the study. Following rating scale is used while analyzing the data.

$\begin{array}{lcc}\text { Strongly Agree } & \text { (SA) } & 1.00-1.50 \\ \text { Agree } & \text { (A) } & 1.51-2.50 \\ \text { Undecided } & \text { (UD) } & 2.51-3.50 \\ \text { Disagree } & \text { (DA) } & 3.51-4.50 \\ \text { Strongly Disagree } & \text { (SDA) } & 4.51-5.00\end{array}$

\section{FINDINGS}

On the basis of the results, following main findings are elicited:

1. Majority of the girls are Agreed $(\mathrm{M}=2.18, \mathrm{SD}=1.18)$ that they were not consulted, while deciding about their higher education.

2. A great mass of the respondents are Agreed $(\mathrm{M}=2.13, \mathrm{SD}=1.17)$ that pick and drop facilities were not properly provided by the universities.

3. Most of the respondents are Agreed $(M=2.20, S D=1.17)$ that females have low access to higher education.

4. A huge gathering of the respondents are Agreed $(\mathrm{M}=2.15, \mathrm{SD}=1.15)$ that there were insufficient Universities to promote female education.

5. Majority of the respondents are Agreed on overall statements of the family structural norms $(\mathrm{M}=2.32$, $\mathrm{SD}=0.69$ ) that caused gender disparity. The standard deviation value falls within +1 . It is inferred that majority of the respondents are in favor that family structural norms are causing gender disparity.

6. No significant differences were found in views of the respondents belonging to urban and rural as the $\mathrm{P}=0.18$, which is greater than the significant level i.e. 0.05 .

\section{CONCLUSIONS}

In the light of findings the following conclusions are drawn:

1. Females were not consulted regarding their higher education which led to gender disparity

2. For female students, proper transport facilities were not being managed by universities which caused problems for them and led to gender disparity.

3. Female low higher education enrollment caused gender disparity.

4. Inadequate and a very small number of women's universities resulted in gender disparity.

5. Family structural norms are not supportive for female education. 
6. Females located in both the areas (urban and rural) were facing the same problem of gender disparity regarding their education. They have the same views that family structural norms are not supporting for their education.

\section{RECOMMENDATIONS}

On the basis of the conclusions the following recommendations are made:

1. To minimize the gender gap in every field and walk of life, the rights of decision making and participating should be given to every individual, irrespective of their gender, caste and ethnicity. Females should have the freedom to make their own decisions, especially regarding their education.

2. Proper transportation facilities should be arranged or managed by parents or universities for female students to minimize the gender gap.

3. It is necessary to enhance females' enrolment in each and every discipline to bring gender equity in education.

4. To reduce the gender disparity, more women s' universities should be established.

5. Legislation should be done at central level as well as at provincial level to enhance the females' enrolment in all tiers of education and all to be streamlined to minimize the gender gap specifically in educational field and commonly in all fields of life.

6. To minimize the gender gap, $50 \%$ seats should be reserved for female students in every discipline in the universities.

\section{References}

Afridi, A. (2003). About Pakistan, CULTURE. [Online] Available: http://www.everyculture.com/No-Sa/Pakistan.html.

Chakarbarti Kr.H. (2001). Empowerment of Women and Sustainable Development. govt/depts. I fbs/statistics/social, statistics/education/PDF. [Online] Available: http://www.Statpak.

Clafer, H.W. (1997). Women and equality changing patterns in American culture; Oxford University Press, USA. [Online] Available: http://en.wikipedia.org/wiki/Culture_of_Pakistan.

Crapo, H.R. (2000). Cultural Anthropology Understanding ourselves and other. McGraw-Hill Companies, Inc, New York, USA, ISBN 0.07-238152-3 Pp. 48, 99-100,369-372.

Federal Bureau of Statistics. (2001-02). Islamabad, Government of Pakistan.

Human development in south Asia. (2000). The Mahbub ul, Haq Human Development Center, Oxford University press: Karachi Pakistan, ISBN; 0195795091.

Hyghes, M. Kroehler, J.C. \& Zanden. V. W.J. (2002). Sociology the Core: Sixth Edition, Mc Graw-Hill, Inc; New York, USA, ISBN 0-07-240535-X.

Isani, A.G.U. \& Virk, L. M. (2005). Higher Education in Pakistan, a historical and futuristic prospective; $2^{\text {nd }}$. Education, National Book Foundation Islamabad, Pakistan.

Khan, A. S. (2000). Gender issues in Higher Education in Pakistan. eprints.hec.gov.pk/1624/1/1182.HTML.

Kottak, P.C. (2002). Cultural Anthropology. McGraw-Hill Companies, Inc: New York, USA. ISBN 0-07-242659-4, P.48.

Mehdi, R. (2007). Gender and Property, law in Pakistan. Maktaba Jadeed press; 9-R always road, Lahore, Pakistan, ISBN-969-402-369-6.

Qureshi, R. \& Rarieya, F.A.J. (2007). Gender and Education is Pakistan. Oxford University press, Inc; UK, London, ISBN 978-0-19-547376-6.

Santrock, W.J. (2004). Educational Psychology. Second Edition, Mc Gram-Hill Companies, Inc; New York, America, ISBN 0-07-250006-9.

Schaefer, T.R. (2003). Sociology, Eight Editions. McGraw-Hill, Inc. New York, USA,

Yasmin, S. (1997). Impact of Higher Education in Understanding of Social Recognition in Women. PhD Thesis. 
Table 1. Views of respondents on Structural Norms

\begin{tabular}{|l|l|c|c|}
\hline S.No & \multicolumn{1}{|c|}{ Statement } & \multicolumn{1}{|c|}{ MD } \\
\hline 1 & $\begin{array}{l}\text { Majority of the girls are not consulted, while deciding about their higher } \\
\text { education. }\end{array}$ & 2.18 & 1.18 \\
\hline 2 & Pick and drop facilities are not properly provided by the universities. & 2.13 & 1.17 \\
\hline 3 & $\begin{array}{l}\text { Parents prefer better academic performance of their sons as compared to their } \\
\text { daughters. }\end{array}$ & 2.94 & 1.38 \\
\hline 4 & Females have low access to higher education. & 2.20 & 1.17 \\
\hline 5 & There are insufficient universities to promote female education. & 2.15 & 1.15 \\
\hline & Over all & 2.32 & 0.69 \\
\hline
\end{tabular}

Table 1 shows the detail of respondents' views regarding the family structural norms which are in vogue in the society. About consultation of females' decision making for higher education, the M value is 2.18 and SD is 1.18, which ranks between the ranges of 1.51-2.50. So, great mass of the respondents are "Agreed", that majority of the girls are not consulted, while deciding about their higher education. Similarly the statement relating to their university transport facilities, the $\mathrm{M}$ value is 2.13 and $\mathrm{SD}$ is 1.17 , which lies between the ranges of 1.51-2.50. Majority of the respondents are "Agreed" that the Pick and Drop facilities are not properly provided by the universities. About parents' academic preference of their children, the M value is 2.94 , and SD is 1.38 , which lies in the range of 3.51-4.50. So, majority of the respondents are "Undecided" on the statement that the Parents do not prefer better academic performance of their sons as compared to their daughters. The statement for females' access to University Education, the M value is 2.20 and $\mathrm{SD}$ is 1.17, which lies in the range of 1.50-2.50. So, majority of the respondents are "Agreed" that the Females have low access to higher education. The statement relating to the availability of higher education institutions, the M value is 2.15 and SD is 1.15 which ranks in between the range of 1.51-2.50. So, the respondents are "Agreed" that there are insufficient Universities to promote female education." Consequently, to the over all conclusion for Family Structural Norms, the M is 2.32 and $\mathrm{SD}$ is 0.69 , which lies in the range of 1.51-2.50. From the $\mathrm{M}$ value it is clear that majority of the respondents are "Agreed" that the Family Structural Norms are not supporting for their education.

Table 2. Comparison of Urban and Rural respondents' views on Family Structural Norms

\begin{tabular}{|c|c|c|c|c|c|}
\hline Location & N & M & SD & t-value & P \\
\hline Urban & 200 & 2.35 & 0.66 & \multirow{2}{*}{0.75} & 0.18 \\
\hline Rural & 200 & 2.39 & 0.71 & & \\
\hline
\end{tabular}

Table 2 depicts that $\mathrm{M}$ for both; the Urban and Rural is 2.35, 2.39 with SD 0.66, 0.71 respectively. The t-value and $\mathrm{P}$-value is 0.75 and 0.18 respectively. The $\mathrm{P}$ value is greater than 0.05 , the level of significance. So, there is no significant difference between urban and rural respondents' views about family structural norms leading to gender disparity. 